\title{
GARMENT NEVUS IN A CHILD: CASE REPORT WITH LITERATURE
}

\author{
Balpreet Kaur ${ }^{1}$, Kallappa Herekal², Karjigi Siddalingappa ${ }^{3}$
}

\section{HOW TO CITE THIS ARTICLE:}

Balpreet Kaur, Kallappa Herekal, Karjigi Siddalingappa. “Garment Nevus in a Child: Case Report with Literature". Journal of Evolution of Medical and Dental Sciences 2015; Vol. 4, Issue 16, February 23;

Page: 2843-2845, DOI: 10.14260/jemds/2015/409

ABSTRACT: Giant pigmented nevi are congenital melanocytic nevi $<1 / 20,000$ births. The appearance of pigmented nevi at birth is not common place. Only $3 \%$ of infants are in born with visible nevi. Here we report a case of a 1 year old female child who presented to us with a large black patch over her back extending up to buttocks with multiple satellite lesions all over the body, since her birth. Their management is a challenge for the treating dermatologist owing to their large size and a propensity to recur. However, there have been recent advances in the field with many new therapeutic modalities available.

KEYWORDS: Garment nevi, congenital melanocytic nevi, and giant melanocytic nevi.

INTRODUCTION: Giant congenital melanocytic nevi, also known as 'garment nevi' or 'bathing trunk nevi', '[1] are large macular lesions with diameters over $20 \mathrm{~cm}$ that are present since birth and develop coarse terminal hair over a period of years. ${ }^{[2]} 1-3 \%$ percent of the newborns have melanocytic nevi at birth. Nevi have been arbitrarily divided into small, intermediate, and giant varieties depending on the size of the lesions, i.e., less than $1.5 \mathrm{~cm}, 1.5 \mathrm{~cm}$ to $20 \mathrm{~cm}$, and more than $20 \mathrm{~cm}$, respectively. ${ }^{[3]}$ The life time risk of malignant transformation in a giant melanocytic nevus ranges from two to 31 percent with an average of $12 \%$ as reported by Kopf et al. (1979).

CASE REPORT: Here, we report the case of a 1-year-old girl who presented to us with an extensive black pigmented lesion of her back extending up to her buttocks [Figure 1]. She had similar lesion over lower abdomen [Figure 2], small black patch over her cheeks with satellite lesions [Figure 3].

She had satellite lesions over lower extremities. She had the pigmentation over her body right from her birth. There is no associated systemic or mucosal anomalies. No history of seizures or focal neurological deficit. None of her family members had similar complaints, and neither was there a family history of consanguineous marriage. Her detailed skin and mucosal examination did not reveal any ulceration or bleeding from the lesions.

On history and clinical examination, there were no signs and symptoms of neurological involvement. A CT scan of the head did not show any deep CNS extension. Fundus examination, ultrasound of the abdomen, and an X-ray of the spine were normal. The biopsy of the patient was taken, and the histopathological findings were consistent with those of congenital melanocytic nevi without any evidence of a malignant transformation in the biopsied lesion.

Other common associated congenital abnormalities like spina bifida, meningocoele, club foot, hypertrophy or atrophy of a limb involved by the nevus, hamartomas such as vascular nevi, lipomas, or von Recklinghausen's disease were not found. She was advised a regular clinical follow-up to detect any malignant transformation at the earliest, if any. 


\section{CASE REPORT}

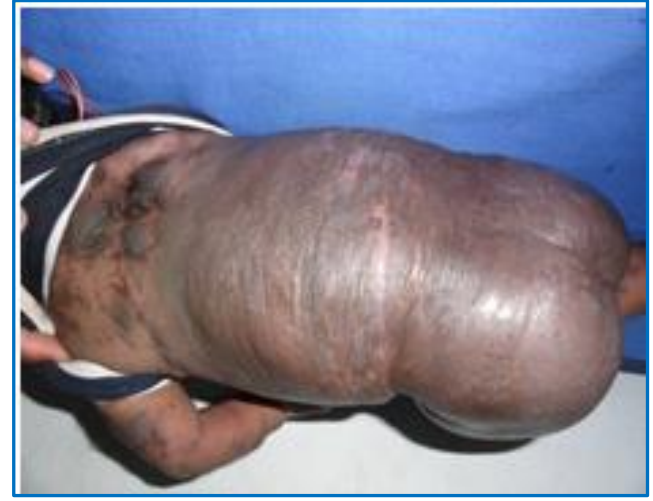

Fig. 1

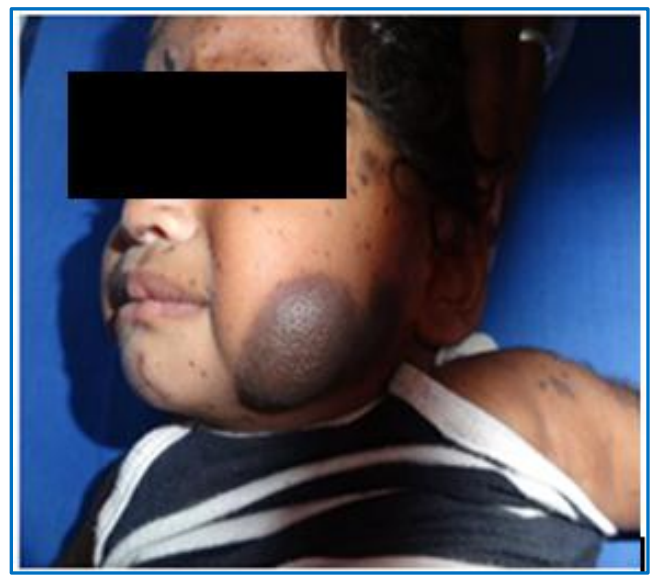

Fig. 3

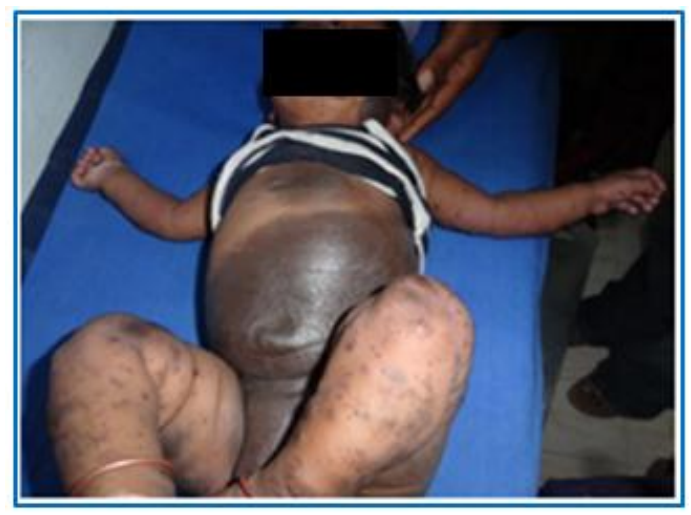

Fig. 2

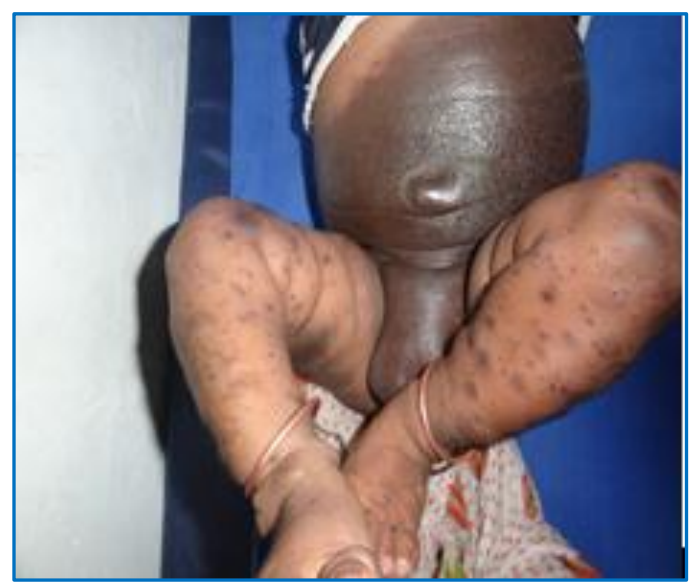

Fig. 4

DISCUSSION: Garment nevi are caused by defects that occur as the fetus grows in utero. Garment nevi may occur with lipomas, neurofibromatosis, other nevi, and spina bifida. ${ }^{[4]}$ There are two main problems faced in managing these giant nevi, one being their potential for malignant change resulting in need for prophylactic removal,[5] and other being the cosmetic concern to the patient. Histopathologically, three patterns may be encountered: A compound or an intra-dermal nevus, a neural nevus, and a blue nevus pattern.[6] The epidermis shows the presence of nevomelanocytes, which, however, may be seen to the mid and the deep dermis as well in the form of sheets, nests, cords giving the characteristic 'Indian file' appearance.[7]

They invade the appendageal and the neurovascular structures as well. Unique to the giant congenital nevi is the occasional presence of nevomelanocytes within the substance of the muscle, bone, placenta, umbilical cord, cranium, and dura mater. ${ }^{[8]}$ Prior to any active intervention planned in this regard whatsoever, it is very prudent to get a biopsy and an MRI (Magnetic resonance imaging) done for two most important reasons. Firstly, to rule out neurocutaneous melanosis, which, if present, may decrease the very need to remove the bulk of the skin lesions as the neural component would still remain inaccessible. Secondly, to rule out the real chance of underlying spinal dysraphism. 
The literature does not show any satisfactory form of treatment for congenital nevus of such dimensions. However, there are various recent modalities of treatment available include staged excision with tissue expansion or grafting, dermabrasion, ${ }^{[9]}$ curettage, $\mathrm{Q}$ switch Ruby laser ${ }^{[1]}$ or erbium: YAG laser.

\section{REFERENCES:}

1. Elder DE, Elenitas R, Murphy GF, Xu X. Benign pigmented lesions and malignant melanoma. In: Lever's Histopathology of the Skin. 9th ed. Philadelphia: Lippincott Williams \& Wilkins; 2005. p. 742-73.

2. MacKie RM. Disorders of cutaneous melanocyte. In: Rook's Textbook of Dermatology. Burns T, Breathnach S, Cox N, Griffiths C, editors. 7th ed. USA: Blackwell Science Ltd.; 2004. p. 38, 18-9.

3. Osburn K, Schosser RH, Everett MA. Congenital pigmented and vascular lesions in newborn infants. J Am Acad Dermatol 1987; 16: 788-92.

4. Bett BJ. Large or multiple congenital melanocytic nevi: Occurrence of neurocutaneous melanocytosis in 1008 persons. J Am Acad Dermatol 2006; 54: 767-77.

5. Kopf AW, MacKie RM. Workshop on congenital naevi. In: Veronesi U, Cascinelli N, Santinami M, editors. Cutaneous Melanoma. London: Academic Press; 1987. p. 261-77.

6. Reed WB, Becker SW Sr, Becker SW Jr, Nickel WR. Giant pigmented nevi, melanoma, and leptomeningeal melanosis. Arch Dermatol 1965; 91: 100-19.

7. Koh HK, Bhawan J. Tumors of the skin. In: Dermatology. Moschella and Hurley, editors. 3rd ed. Philadelphia: Mc-Graw Hill Companies; 1992. p. 1753.

8. Grichnik JM, Rhodes AR, Sober AJ. Benign Neoplasia and Hyperplasia of Melanocytes. Fitzpatrick's Dermatology In General Medicine. In: Wolff K, Goldsmith LA, Katz SI, Gilchrest BA, Paller AS, Leffell DJ, editors. 7th Ed. New York, NY: McGraw Hill; 2003. p. 1101.

9. Congenital melanocytic nevi. In: Habif TP, editor. Clinical Dermatology. 5th ed. Philadelphia, Pa: Saunders Elsevier; 2009. p. 850-1.

\section{AUTHORS:}

1. Balpreet Kaur

2. Kallappa Herekal

3. Karjigi Siddalingappa

\section{PARTICULARS OF CONTRIBUTORS:}

1. $3^{\text {rd }}$ year Post Graduate, Department of Dermatology, Navodaya Medical College, Raichur.

2. Professor \& HOD, Department of Dermatology, Navodaya Medical College, Raichur.

FINANCIAL OR OTHER COMPETING INTERESTS: None
3. Professor, Department of Dermatology, Navodaya Medical College, Raichur.

NAME ADDRESS EMAIL ID OF THE CORRESPONDING AUTHOR:

Dr. Kallapa Herekal

C/O. Department of Dermatology

Navodaya Medical College,

Raichur.

E-mail: drkallapa@gmail.com

Date of Submission: 05/01/2015. Date of Peer Review: 06/01/2015. Date of Acceptance: 13/02/2015. Date of Publishing: 23/02/2015. 